\title{
The combination of green tea, caffeine, conjugated linoleic acid and branched chain amino acids have no effect on body composition and abdominal fat changes in overweight and obese men and women
}

\author{
D David Thomas, Shweta Rawal, Amber W Kinsey, Wyatt E Eddy, Nicholas Fisher, Maria M Spicer, \\ Michael J Ormsbee* \\ From International Society of Sports Nutrition: 9th Annual ISSN Conference and Expo \\ Clearwater, FL, USA. 22-23 June 2012
}

\section{Background}

Caffeine, conjugated linoleic acid (CLA), green tea and branched chain amino acids (BCAA) have shown to individually improve body composition in overweight and obese men and women. The purpose of this study was to investigate the effects of a multi-ingredient dietary supplement containing caffeine, CLA, green tea, and BCAA on body composition and abdominal fat mass in overweight and obese men and women.

\section{Methods}

Thirty-four healthy men and women were randomly assigned to two groups: 1) a soybean oil placebo (PL) or 2) a multi-ingredient dietary supplement (DS) containing 99 $\mathrm{mg}$ of caffeine and a propriety blend containing $1510 \mathrm{mg}$ of CLA, green tea extract (45\% EGCG), L-leucine, L-isoleucine and L-valine. Twenty-two participants completed the study (PL: $\mathrm{n}=11$; age, $34 \pm 12$ years; body mass, $97.0 \pm$ $22.6 \mathrm{~kg}$; BMI, $34.1 \pm 6.1$; DS $n=11$; age, $36 \pm 11.1$ years; body mass, $91.9 \pm 18.7 \mathrm{~kg}$; BMI, $30.0 \pm 4.9)$. Both groups consumed two pills with breakfast and two pills with lunch. Body composition and android fat (dual-energy $\mathrm{X}$-ray absorptiometry), waist and hip circumferences, blood pressure and heart rate were measured at baseline and after 8 weeks of supplementation. Participants were instructed to maintain normal dietary and exercise habits for the duration of the study. Data was analyzed using JMP 9 Pro (Cary, NC), significance was set to $p<0.05$. A two-way ANOVA with repeated measurements was used to evaluate changes in dependent variables over time ([Pre $x$ Post] $x$ [PL $x$ DS]). If significant time, group, or groupby-time interactions were reported, a Tukey test was used for post hoc comparisons.

\section{Results}

Twenty two participants finished the study. Five participants dropped the study due to personal reasons and seven were excluded from the data due to low compliance $(<80 \%)$ to the supplement. No significant changes were measured in body composition, android fat, waist or hip circumference, heart rate and blood pressure.

\section{Conclusion}

Eight weeks of supplementation of a multi-ingredient supplement containing caffeine, CLA, green tea, and BCAA did not affect body composition, android fat, heart rate, or blood pressure in overweight and obese men and women.

\section{Acknowledgements}

This study was supported by a grant from the International Society of Sports Nutrition.

Published: 19 November 2012

\footnotetext{
* Correspondence: mormsbee@fsu.edu

Department of Nutrition, Food and Exercise Science, The Florida State University, Tallahassee, FL 32306, USA
}

C 2012 Thomas et al; licensee BioMed Central Ltd. This is an Open Access article distributed under the terms of the Creative Commons 
doi:10.1186/1550-2783-9-S1-P29

Cite this article as: Thomas et al: The combination of green tea,

caffeine, conjugated linoleic acid and branched chain amino acids have

no effect on body composition and abdominal fat changes in

overweight and obese men and women. Journal of the International

Society of Sports Nutrition 2012 9(Suppl 1):P29.

Submit your next manuscript to BioMed Central and take full advantage of:

- Convenient online submission

- Thorough peer review

- No space constraints or color figure charges

- Immediate publication on acceptance

- Inclusion in PubMed, CAS, Scopus and Google Scholar

- Research which is freely available for redistribution

Submit your manuscript at 